\title{
To Study the Influence of Blend Ratio of Sorghum and Soybean Flour on Overall Acceptability of the Different Pasta Products
}

\author{
Moradiya PB, Gojiya DK* and Vyas DM \\ Junagadh Agriculture University, India \\ *Corresponding author: Gojiya DK, Junagadh Agriculture University, Junagadh, Gujarath, India
}

Submission: 侮 April 12,2018; Published: 侮July 05, 2018

\begin{abstract}
Extrusion technology has played an increasingly important role in many industries such as food, feed and polymer over the last few decades. Pasta products are the most ancient source of food consumed form of wheat. The principal object of the present investigation was to prepare an improved pasta product enriched with protein and other nutritional components by blending Soyabean flour, Sorghum flour. The optimization of the variable for the development of the best quality pasta product was done blend ratio of Sorghum and Soyabean flour (70:30, 60:40, 50:50, 40:60 and 30:70) have been optimized for overall acceptability of pasta products. Considering the analysis of observations sensory properties it was observed that the percentage of Soyabean and Sorghum flour played an important role in overall acceptability of pasta products. The highest value of overall acceptability for raw pasta with 70-30\% blend (Sorghum to Soyabean flour) for all the shapes considered was found as 6.61, 7.01, 6.76 and 6.70, respectively. While in case of cooked pasta the maximum overall acceptability with 70-30\% blend (Sorghum to Soyabean flour) for all the shapes was found as 6.92, 7.06, 7.02 and 6.76, respectively. While for fried pasta the highest overall acceptability with 70-30\% blend (Sorghum to Soyabean flour) for all the shapes was observed as $6.79,6.81,6.70$ and 6.64 , respectively.
\end{abstract}

Keywords: Blend ratio; Extrusion; Pasta; Sorghum flour; Soybean flour; Sensory

\section{Introduction}

Extrusion is a cooking and shaping process designed to give unique physical and chemical functionality to food materials. Durum wheat is the main raw material used to produce good quality semolina. To form the plastic type of dough used for pasta processing, semolina is mixed with water, representing $31 \%$ of the weight of the semolina. There are many different shapes and sizes of pasta. The popularity of pasta can be attributed to its sensory appeal, versatility, low cost, ease of preparation, nutritional content and excellent storage stability. All the pasta products are basically similar but differing mainly in shape.

While most are made from wheat, other grains can also be used on their own or combined with wheat. As a wheat-derived staple food, pasta is second only to bread in the world consumption. It is nearly worldwide acceptance due to its low cost, ease of preparation, versatility, sensory attributes and long shelf life. Most pasta shapes are made with extrusion dies, in which fresh pasta dough is pushed through a shape forming disc and then cut to size [1].

Quality is a major consideration in the preparation of any food products. Several products in the recent years, which made a big hit when they were introduced, have dropped out of the market because of the lack of proper quality parameters. Quality has to be established both for the inputs as well as for the products. Physical characteristics are more important in evaluating the extruded chunks. The trade has set values on uniformity in size, texture, bulk density, taste, flavour and colour which greatly depends on the raw material and operating parameters [2].

No single legume or cereal can provide adequate amount of all nutrients. However, even before knowledge on protein content, protein quality, digestibility and the nutrient requirements for humans became available, it was recognized that mixing of legumes and cereals in the diet could improve overall nutrition. Moreover, the use of blends of wheat and non-wheat flours, known as composite flour, became prevalent when wheat was scarce.

Sorghum is a staple food grain in many semi-arid and tropic areas of the world, because of its good adaptation to hard environment and its good yield of production. Amongst important biochemical components of sorghum, are the levels of starch and starch depolymerising enzymes. Due to presence of high amount of starch (56-73\%), sorghum could be the good commodity for preparing of expanded snacks [3].

Soyabean protein has been the subject of intense investigation and has played an increasing role in human nutrition over the last 
few decades. Soy protein products are an ideal source of some of the essential amino acids used to complement cereal proteins. At present, soy proteins are more versatile than many other food proteins in various worldwide nutritional programs.

The protein supplementation of cereals is desirable in many instances because cereals have low protein contents and are imbalanced in essential amino acid composition. As a result, cereal grains do not supply adequate protein for satisfactory growth of infants and children or for the bodily maintenance of adults.

The present and newly derived knowledge in these areas makes it possible to blend, mix or fortify one food material with others so that the resulting fortified mix has not only better nutritional quality but also attributes for consumer acceptance. The nutritional quality of sorghum and wheat, especially the former, is poor. Therefore, attempts have been made to fortify these cereals with legumes to make nutritionally superior and acceptable products [4].

The principal object of the present investigation was to prepare an improved pasta product enriched with protein and other nutritional components by blending Soyabean flour, Sorghum flour which has also good texture, shape, taste and all the attributes of the best pasta products [5]

\section{Materials and Methods}

Present investigation was conducted at the Department of Processing and Food Engineering, College of Agricultural Engineering \& Technology, Junagadh Agricultural University, Junagadh.

\section{Pasta machine}

The Dolly pasta machine (Plate 3.1) manufactured by "La Monferrina" di A. Mascero and C. snc. Manufacturing company (Italy) was used for extrusion of pasta of Sorghum and Soyabean flour with five different blend ratios [6]. The machine had a pure, unalterable stainless steel structure. The main components of the machine were single phase $220 \mathrm{~V}$ or three phase $380 \mathrm{~V}$ electric motor, stainless steel tank with mixing shaft, stainless steel screw, dies for every type of dough and automatic dough cutter with speed variator and stainless steel blade and control panel (Figure 1).

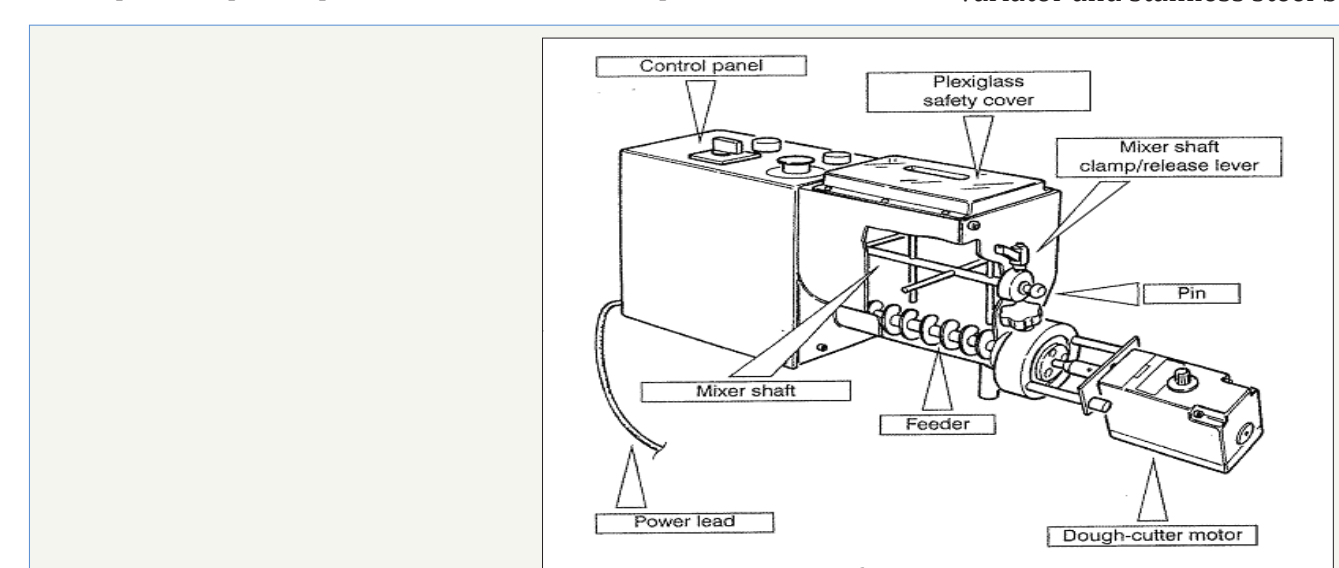

Figure 1: Schematic view of Dolly pasta machine.

\section{Preparation of raw material}

The required quantity of Soyabean, Sorghum and Maida were purchased from the local market. Soyabean and Sorghum were floured and sieved through 28 meshes while Maida through 48 mesh sieve. All the three flours were mixed together to prepare five different samples [7]. However, 15\% (by weight) Maida was added rationally in all the five samples. While remaining $85 \%$ (by weight) of sample was prepared by taking different ratios of Sorghum and Soyabean flour as shown below

The ratios were,
a. $\quad 70 \%$ Sorghum $+30 \%$ Soyabeanflour + Maida
b. $\quad 30 \%$ Sorghum $+70 \%$ Soyabean flour + Maida
c. $40 \%$ Sorghum $+60 \%$ Soyabean flour + Maida
d. $60 \%$ Sorghum $+40 \%$ Soyabean flour + Maida
e. $\quad 50 \%$ Sorghum $+50 \%$ Soyabean flour + Maida

\section{Preparation of pasta}

For the preparation of raw pasta, the mixing tank was filled with basic ingredients followed by addition of 31\% (Garg, 2005) pure water in the flour and then safety cover was closed. The machine was started with kneading position. After kneading the material for about 15 minutes to get the homogeneous mix, the machine was set from previous kneading position to the extruding position. The material was extrudated in four different shapes using the four types of dies. Subsequently, pasta was allowed to dry in shed from moisture content approximately 30 to $9 \pm 1 \%$ (w.b).

The boiled pasta was prepared by placing the dried raw pasta into the boiling water. The cooking time was recorded when the center ring of the pasta became cooked. The cooked pasta was allowed to shed drying for 2 days [8]. Similarly, the dried raw pasta was fired in pure ground nut oil to get the fried pasta. The raw (dried), cooked (dried) and fried pasta were stored in polyethylene bags. One corresponding sample was taken from bag to measure physical, functional, biochemical and textural properties.

\section{Sensory evaluation}

Sensory properties are defined as those characteristics of food that are detected by the sensory organs. The production of finished food by the farmer or food processor implies that the consumer will accept these products that the product has a certain quality. Sensory attributes of quality guide the consumer in his selection 
food. Some common terms expressing these sensory sensations are appearance, colour, taste, texture, visual surface properties and overall acceptability.

Ten judges were selected for the panel to ensure uniform quality or to detect the difference in product quality between process and raw material from the faculty and staff member of department. All the members were trained to use score sheet and understand the criteria for evaluating the sensory attributes [9].

The samples were coded before serving and taken from a table of random numbers. Samples were presented to the panel at a time for the evaluation of the sensory attributes such as colour, appearance, visual surface properties (smoothness, and uniformity in diameter), taste and overall acceptability of developed products [10].

\section{Result and Discussion}

Overall acceptability of the different pasta products prepared with different blend ratio of Sorghum and Soybean flour (Table 1).

Table 1: ${ }^{\mathrm{a}}=$ Satisfactory, ${ }^{\mathrm{b}}=$ Fair, ${ }^{\mathrm{c}}=$ Poor .

\begin{tabular}{|c|c|c|c|c|c|c|}
\hline \multirow{2}{*}{ Sr. No. } & \multirow{2}{*}{ Blend ratio, \% } & \multirow{2}{*}{ Status } & \multicolumn{4}{|c|}{ Overall acceptability } \\
\hline & & & S1 & S 2 & S 3 & S 4 \\
\hline 1 & 70:30:00 & \multirow{5}{*}{ Raw } & $6.61^{\mathrm{a}}$ & $7.01^{\mathrm{a}}$ & $6.76^{\mathrm{a}}$ & $6.70^{\mathrm{a}}$ \\
\hline 2 & $60: 40: 00$ & & $6.38^{\mathrm{b}}$ & $6.73^{\mathrm{a}}$ & $6.69^{\mathrm{a}}$ & $6.32^{\mathrm{b}}$ \\
\hline 3 & $50: 50: 00$ & & $6.16^{\mathrm{b}}$ & $6.45^{b}$ & $6.34^{\mathrm{b}}$ & $6.34^{\mathrm{b}}$ \\
\hline 4 & $40: 60$ & & $5.71^{b}$ & $6.02^{\mathrm{b}}$ & $5.75^{\mathrm{b}}$ & $6.25^{\mathrm{b}}$ \\
\hline 5 & $30: 70$ & & $4.97^{c}$ & $5.57^{\mathrm{b}}$ & $5.20^{\mathrm{b}}$ & $5.74^{\mathrm{b}}$ \\
\hline 6 & $70: 30: 00$ & \multirow{5}{*}{ Cooked } & $6.92^{\mathrm{a}}$ & $7.06^{\mathrm{a}}$ & $7.02^{\mathrm{a}}$ & $6.76^{\mathrm{a}}$ \\
\hline 7 & $60: 40: 00$ & & $6.73^{\mathrm{a}}$ & $7.03^{\mathrm{a}}$ & $6.79^{\mathrm{a}}$ & $6.61^{\mathrm{a}}$ \\
\hline 8 & $50: 50: 00$ & & $6.41^{b}$ & $6.67^{\mathrm{a}}$ & $6.48^{b}$ & $6.38^{b}$ \\
\hline 9 & $40: 60$ & & $6.34^{b}$ & $6.45^{b}$ & $6.37^{\mathrm{b}}$ & $6.39^{b}$ \\
\hline 10 & $30: 70$ & & $6.04^{b}$ & $6.06^{b}$ & $6.11^{\mathrm{b}}$ & $6.04^{b}$ \\
\hline 11 & 70:30:00 & \multirow{5}{*}{ Fried } & $6.79^{a}$ & $6.81^{\mathrm{a}}$ & $6.70^{\mathrm{a}}$ & $6.64^{\mathrm{a}}$ \\
\hline 12 & $60: 40: 00$ & & $6.47^{b}$ & $6.47^{b}$ & $6.55^{\mathrm{b}}$ & $6.32^{\mathrm{b}}$ \\
\hline 13 & $50: 50: 00$ & & $6.47^{\mathrm{b}}$ & $6.41^{b}$ & $6.50^{\mathrm{b}}$ & $6.27^{b}$ \\
\hline 14 & $40: 60$ & & $6.05^{b}$ & $6.19^{b}$ & $6.02^{\mathrm{b}}$ & $5.98^{b}$ \\
\hline 15 & $30: 70$ & & $5.49^{b}$ & $6.13^{b}$ & $5.53^{\mathrm{b}}$ & $5.94^{\mathrm{b}}$ \\
\hline
\end{tabular}

The score for the 10-point scale (where 9-10=excellent 8-8.9=good, 6.6-8.8=satisfactory, 5-6.5=fair and $<5=$ =poor) for the sensory overall acceptability of the prepared pasta products are shown in table for all shapes. The overall acceptability of the pasta products prepared from 30:70 blend ratios was lowest while the same was highest of the pasta prepared from 70:30 blend ratios. In respect of frying oil temperature the overall.
Acceptability of all the three types of pasta products prepared with 30\% Sorghum flour and 70\% Soyabean flour was found lowest while that was highest for the pasta prepared with 70\% Sorghum flour and 30\% Soyabean flour all shapes. The highest value of overall acceptability for raw pasta with $70-30 \%$ blend (Sorghum to Soyabean flour) for shape 1, 2, 3 and 4 was found as 6.61, 7.01, 6.76 and 6.70 , respectively. While in case of cooked pasta the overall acceptability with $70-30 \%$ blend (Sorghum to Soyabean flour) for shape 1, 2, 3 and 4 was found as 6.92, 7.06, 7.02 and 6.76, respectively. While for fried pasta the overall acceptability with 70 $-30 \%$ blend (Sorghum to Soyabean flour) for shape 1, 2, 3 and 4 was found as $6.79,6.81,6.70$ and 6.64 , respectively.

The smoothness, taste and colour of pasta products were decreasing as the percentage of Soyabean flour increase in the blend. The results obtained for sensory properties of the pasta products prepared considering different blend ratios were in line with the results obtained by Singh et al. [1] and Singh [2] and Shogren et al. [3] in case of pasta prepared by blending of light and dark buckwheat, amaranth and lupin flour, wheat and rice semolina with potato grits, wheat, rice peanut and chickpea flour and durum wheat and soybean flour, respectively.

\section{Conclusion}

During sensory evaluation it was observed that that all the sensory parameters were significantly influenced both by blend ratio. The highest value of overall acceptability for raw pasta with 70-30\% blend (Sorghum to Soyabean flour) for shape 1, 2, 3 and 4 was found as $6.61,7.01,6.76$ and 6.70 , respectively. While in case of cooked pasta the maximum overall acceptability with $70-30 \%$ blend (Sorghum to Soyabean flour) for shape 1, 2, 3 and 4 was found as 6.92, 7.06, 7.02 and 6.76, respectively. While for fried pasta the highest overall acceptability with $70-30 \%$ blend (Sorghum to Soyabean flour) for shape 1, 2, 3 and 4 was found as $6.79,6.81,6.70$ and 6.64, respectively.

\section{References}

1. Singh N, Singh B, Sandhu KS, Bawa AS, Sakhon KS (1996) Extrusion behaviour of wheat rice and potato blends. J Food Sci Technol 33(4): 3541.

2. Singh SN (2004) Studies on peanut blended extruded products. M Tech (Agri Engg) Thesis (Unpublished), Junagadh Agricultural University, Junagadh, India.

3. Shogren RL, Hareland GA, Wu YV (2006) Sensory evaluation and composition of spaghetti fortified with soy flour. Journal of Food Science 71(6): 1750-3841.

4. AOAC (1996) Official methods of analysis. Association of official agricultural chemists, Washington, USA.

5. Anonymous (2011) Annual Report 2011. Director of Agriculture, Government of Gujarat, Gandhi Nagar, India.

6. Anonymous (2012) Agricultural Statistics at a Glance 2012. Directorate of Economics \& Statistics, Ministry of Agriculture, Government of India, New Delhi, India.

7. Bhattacharya S, Sudh ML, Rachim A (1999) Pasting characteristics of an extruded blend of potato and wheat flours. Journal of Food Engg 40(12): 107-111. 
8. Oh NH, Seib PA, Deyoe CW, Ward AB (1985) Noodles. II. The surface firmness of cooked noodles from soft and hard wheat flours. Cereal Chemistry 62(6): 431-436.

9. Oh NH, Seib PA, Ward AB, Deyoe CW (1985) Noodles. VI. Functional properties of wheat flour components in oriental dry noodles. Cereal Foods World 30(2): 176.
10. Sadasivam S, Manikam A (1992) Biochemical methods of agricultural science. Wiley Eastern Ltd, New Delhi, India.
For possible submissions Click Here

Submit Article

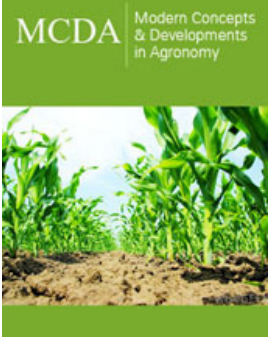

Modern Concepts \& Developments in Agronomy

\section{Benefits of Publishing with us}

- High-level peer review and editorial services

- Freely accessible online immediately upon publication

- Authors retain the copyright to their work

- Licensing it under a Creative Commons license

- Visibility through different online platforms 